\title{
Malignant Glottis Neoplasm
}

National Cancer Institute

\section{Source}

National Cancer Institute. Malignant Glottis Neoplasm. NCI Thesaurus. Code C3544.

A malignant neoplasm that affects the glottic area of the larynx. The vast majority of cases represent squamous cell carcinomas. 